has not, however, yet been traced far to the west; and its distinction from the contemporary faunas of Europe indicates that Indian waters formed a separate zoological province in Palæocene times. Many European species appear in the succeeding Laki, however, and the foraminiferal fauna of the Khirthar is very similar to that of the Lutetian. Thus the isolation of Indian waters during the early Tertiary appears to have been limited to the Palæocene.

8 Garscube Terrace,

L. M. Davies.

Edinburgh, 12.

Jan. 29.

${ }^{1}$ NATURE, 135, 188 (Feb. 2, 1935).

\section{Racial Theory and Cross-breeding}

Crosses have been the great stumbling block in the path of physical anthropology. Different races can and do breed together, therefore there can be no such thing as a race of men, if by race we mean the human equivalent of a breed of dogs or horses. Anthropologists allow an exception where deserts or other obstacles isolate one lineage from another.

They overlook the possibility that man may be isolated by his own action, by his language, his custom, even by his own decision. In practice, lineages do isolate themselves for breeding purposes where there is no external necessity, just because they like to do so. Not being a physical anthropologist, I have not pursued the facts systematically from the point of view of breeding, but such facts as have come my way in the pursuit of other aims seem to raise two questions which have not been given proper consideration:

1. Is cross-breeding really common ?

2. Does such cross-breeding as takes place leave much trace in the long run ?

1. In a commune near Alexandria, 'Ali Ahmed 'Isa Eff. counted 53 marriages in two years, of which 23 were within the village or hamlet; 7 were outside the village or hamlet, but within the commune; 13 were outside the commune, but into neighbouring communes; 10 were into towns round about. It is common knowledge that English peasants used until recently to view with disfavour marriages with 'foreigners', that is, strangers to the village.

I can only record the impression left by a Guernsey pedigree now unfortunately lost. Marriages went on mostly within a small group of families. First cousin marriage between two of those families never failed for several generations. Of three marriages I remem. ber outside the circle, all encountered opposition.

Writings on exogamy have encouraged the idea that it means compulsory breeding out. As a matter of fact, it is generally not a system of enforcing marriage outside the family, but of restricting it to another branch than one's own, exactly as happened between the two Guernsey families above (cf. Genesis, xxiv and xxviii, and my "Progress of Man", $239 \mathrm{ff}$.). The exclusiveness of Indian lineages is notorious and extreme, and they constantly split up into lineages exclusive of one another.

These are only a few of the facts.

2. Anthropologists get their impressions from middle-class practice. This class is addicted to promiscuous breeding; in fact, it may be said to be characteristic. The middle classes, however, appear to be dying out, not for the first time in history (see notably S. Dill, "Roman Society in the Last Century of the Roman Empire"). It seems doubtful whether townsfolk generally last many generations. We know that towns are constantly recruited from the country. This is particularly so in Paris. Eventually, towns dwindle and sometimes disappear altogether.

To take a concrete case. The North Central Province of Ceylon was once thickly populated all around an extensive capital. It is now reduced to a miserable remnant of peasants living in small hamlets. From whom are they descended ? From the ancient city population? But we have no evidence that city populations ever return to the soil in any numbers, if at all. They can only be descended from the peasants. That is only one of countless cases.

This brings us face to face with a phenomenon which is seldom faced because it is not pleasant. Communities flare up and die down. Therefore only a small fraction carries on the breed. Who ? There is every appearance that it is the peasantry, which is most given to self-imposed isolation.

We can no longer be content to note that crossbreeding occurs; we must observe its consequences for generations, instead of assuming them.

Perhaps if we do so we shall find out a great deal more than by the study of animals, which is experimental, and so works under the unnatural conditions of the laboratory. In observing man, we observe what happens in Nature. When we watch human lineages isolating themselves, we may get the clue to the segregation of species in Nature.

\section{Shagaret el Dur, Zamalek,} A. M. Hocart. Cairo.

\section{Negative Protons in Cosmic Radiations}

At Asmara, magnetic lat. $11^{\circ} 30^{\prime}$, Rossi ${ }^{1}$ and Benedetti ${ }^{2}$ have counted the number of coincidences between two counters mounted with their axes parallel in such a way that the plane containing them could be rotated about a parallel axis so as to make any given angle with the vertical at the point. They have measured the diminution in the number of coincidences caused by introducing lead between the counters, and also by rotating the plane of the counters so as to make various angles $\theta$ with the meridian plane. Certain conclusions follow from these experiments which we shall now deduce.

Benedetti has measured the number of coincidences in the following three cases :

$\begin{array}{ccc}\begin{array}{c}\text { Arrange- } \\ \text { ment. }\end{array} & \begin{array}{r}\text { Thickness of } \\ \text { lead between } \\ \text { the counters. }\end{array} & \begin{array}{c}\text { Angle } \theta \text { to } \\ \text { the west. }\end{array} \\ \text { (1) } & 4 \mathrm{~cm} . & 0^{\circ} \\ (2) & 16 \mathrm{~cm} . & 0^{\circ} \\ (3) & 4 \mathrm{~cm} . & 30^{\circ}\end{array}$

Rate/minute. $0.625+0.010$ $0.575 \pm 0.009$ $0 \cdot 516 \pm 0 \cdot 009$

The decrease between (1) and (3) is about twice the decrease between (1) and (2). Since at the height of Asmara $12 \mathrm{~cm}$. of lead corresponds in mass to the extra thickness of atmosphere in going from the vertical to $\theta=30^{\circ}$, the difference between ( 1 ) and (3) might be ascribed to the greater absorption due to the same mass of air. This possibility can, however, be excluded by tho experiments of Street, Woodward and Stevenson ${ }^{3}$, who have measured the absorption in lead, iron and marble, and of clay and his co. workers ${ }^{4}$, who have measured it in various substances including water. These investigators find 